\title{
Pengaruh Pemberian Jus Tomat (Solanum lycopersicum) terhadap Jumlah Sel Radang di Alveolus Tikus Wistar (Rattus norvegicus) yang Dipapar Asap Rokok Kretek Subkronik
}

\author{
Dewi Mustika1, Subandi² \\ ${ }^{1}$ Laboratorium Fisiologi, Fakultas Kedokteran, Universitas Brawijaya \\ ${ }^{2}$ Laboratorium Anatomi Histologi, Fakultas Kedokteran, Universitas Brawijaya \\ Email: dewimustika@ub.ac.id, subandi@ub.ac.id
}

\begin{abstract}
ABSTRAK
Asap rokok mengandung radikal bebas yang dapat menyebabkan proses inflamasi pada saluran nafas. Peningkatan jumlah sel radang pada alveolus paru dapat semakin meningkatkan kondisi stres oksidatif dikarenakan sel radang juga memicu timbulnya radikal bebas. Oleh karena itu, pemberian antioksidan diharapkan dapat mengurangi proses keradangan pada alveolus paru. Tujuan dari penelitian ini untuk membuktikan pengaruh pemberian jus tomat, yang mengandung likopen, betakaroten, dan vitamin c, terhadap penurunan jumlah sel radang alveolus tikus Wistar jantan yang dipapar asap rokok subkronik. Pemaparan asap rokok dilakukan selama 9 minggu menggunakan smoking pump, dilanjutkan dengan pemberian jus tomat dengan dosis 1,15; 2,3; dan 4,6 ml/tikus perhari selama 3 minggu. Setelah 12 minggu, jaringan paru setiap tikus diambil, kemudian dibuat sediaan histopatologi dengan pengecatan HE. Sediaan diamati menggunakan mikroskop pada 10 lapang pandang untuk dilakukan penghitungan jumlah sel radang (neutrofil, limfosit, makrofag) yang terdapat pada septa interalveolaris. Data dianalisis menggunakan One-Way ANOVA dilanjutkan uji Post hoc Tukey. Hasil penelitian menunjukkan bahwa pemberian jus tomat dapat menyebabkan penurunan jumlah sel radang di alveolus pada ketiga dosis yang diberikan $(p=0,000)$. Hasil uji korelasi Pearson menunjukkan bahwa semakin tinggi dosis jus tomat $(0 ; 1,15 ; 2,3 ; 4,6 \mathrm{ml} / \mathrm{hari})$ maka akan semakin menurunkan jumlah sel radang di alveolus $(r=-0,868 ; p=0,000)$. Dari penelitian ini dapat disimpulkan bahwa pemberian jus tomat setelah paparan asap rokok dapat menurunkan jumlah sel radang di alveolus.
\end{abstract}

Kata kunci: alveolus, asap rokok subkronik, jumlah sel radang, jus tomat (likopen).

\begin{abstract}
Cigarette smoke contains free radicals that cause inflammation of respiratory tract. The increased numbers of alveolar inflammatory cells may amplify the level of oxidative stress, because inflammatory cells also induce free radicals. Therefore, antioxidant administration is expected to reduce the inflammatory process in the lung. The objective of this research is to prove the effect of tomato juice supplementation which contains lycopene, $\beta$-carotene and vitamin $C$ on the numbers of alveolar inflammatory cells in the rat which previously is exposed to sub chronic cigarette smoke. Exposure to cigarette smoke conducted for 9 weeks using a smoking pump followed by supplementation of tomatoes juice with a dose of $1.15 ; 2.3$; and 4.6 $\mathrm{ml} /$ rat per day for 3 weeks. After 12 weeks, every mouse was euthanized and the lung was removed to made histopathologic preparations with HE staining. The preparations were observed on microscope and were selected 10 fields for calculating the number of inflammatory cells (neutrophils, lymphocytes, macrophages) in the interalveolar septa. Data analysis using One-Way ANOVA method followed by Post hoc Tukey test. The result showed that tomato juice could cause decrease of inflammation cell numbers in alveolus at three doses given $(p=0,000)$.
\end{abstract}


Pearson correlation test results showed that the higher the dose of tomato juice $(0,1.15,2.3,4.6$ $\mathrm{ml} /$ day) will further decrease the number of inflammatory cells in the alveoli $(\mathrm{r}=-0,868 ; \mathrm{p}=$ 0,000 ). It is concluded that the administration of tomato juice after exposure to cigarette smoke can reduce the number of inflammatory cells in the alveoli.

Keywords: tomato juice (lycopene), sub chronic cigarette smoke, alveolar inflammatory cells.

\section{PENDAHULUAN}

Merokok merupakan faktor resiko terbesar kedua yang menyebabkan mortalitas dan morbiditas di usia yang lebih muda (1). Rokok membunuh satu orang setiap 6 detik dan sekitar 6 juta orang per tahun di seluruh dunia (2). Diperkirakan 1,25 milyar perokok di seluruh dunia dimana 800 juta diantaranya tinggal di negara berkembang (3). Asap rokok merupakan aerosol yang mengandung $10^{10}$ partikel/mL dan 3500 kompenen kimia didalamnya bersifat toksik dan mutagen (4). Sekali hisap, terdapat $10^{15}$ radikal bebas yang dapat dipertahankan dalam waktu cukup lama ( $>10$ menit). Partikel dari asap rokok ini berukuran sangat kecil $(0,1-1,0 \mu \mathrm{m})$ sehingga dapat melakukan penetrasi hingga ke alveoli (4).

Dalam kaitannya dengan inflamasi, radikal bebas dalam asap rokok mengiritasi secara langsung melalui partikel-partikelnya yang iritatif maupun melalui efek lanjutan dari kerusakan sel. Efek kerusakan jaringan ini terjadi karena proses stress oksidatif. Radikal bebas dalam rokok akan menyebabkan materi biologis mudah teroksidasi. Termasuk didalamnya adalah membran sel epithel saluran pernafasan dan alveolus yang banyak mengandung poliunsaturated lipid. Keadaan inilah yang menjadi salah satu penyebab rusaknya sel epithel dan alveolus $(4,5)$. Sel yang rusak ini akan mengeluarkan mediator inflamasi yang pada akhirnya menarik datangnya sel-sel radang (6).

Selain melalui proses oksidasi lemak, radikal bebas juga mampu menyebabkan peningkatan aktivasi faktor transduksi dan transkripsi gen inflamasi yang pada akhirnya menyebabkan peningkatan sel radang. Keradangan yang diakibatkan oleh asap rokok secara khas ditandai dengan peningkatan jumlah makrofag, neutrofil, dan limfosit T serta pelepasan berbagai mediator inflamasi (lipid, kemokin, sitokin growth factor) (7). Merokok memiliki efek stimulator langsung terhadap produksi granulosit terutama meningkatkan retensi neutrofil di paru. Selain itu makrofag perokok memiliki waktu hidup lebih lama dikarenakan peningkatan ekspresi protein anti apoptosis Bcl-X $\mathrm{X}_{\mathrm{L}}$ dan peningkatan ekspresi p21 CIP/WAF1 pada sitoplasmanya. Peningkatan jumlah total limfosit $\mathrm{T}$ pada parenkim paru telah terbukti berhubungan dengan kerusakan alveolus $(6,8,9)$.

Akibat dari proses inflamasi, saluran nafas mengalami hambatan karena deposisi kolagen, hipersekresi mukus dan penambahan eksudat inflamasi termasuk juga sel radang. Kedatangan sel radang akan semakin meningkatkan kondisi stres oksidatif karena sel radang juga menghasilkan radikal bebas. Keadaan ini pada akhirnya dapat memunculkan penyakit paru obstruktif menahun (10).

Dalam kondisi stres oksidatif yang meningkat akibat asap rokok, dibutuhkan tambahan antioksidan dari luar tubuh sebagai penyeimbang meningkatnya radikal bebas (11). Kecenderungan masyarakat saat ini adalah memilih mengkonsumsi bahanbahan yang alami karena diyakini lebih aman dari kemungkinan-kemungkinan efek samping. Salah satu tanaman yang mengandung antioksidan adalah tomat (12).

Tomat relatif kaya akan antioksidan, diantaranya adalah likopen (59 mg/kg), vitamin C (160-240 $\mathrm{mg} / \mathrm{kg})$, provitamin A karoten $(6-9 \mathrm{mg} / \mathrm{kg})$ dan komponen phenolic: flavonoids (5-50 mg/kg) dan phenolic acids $(10-50 \mathrm{mg} / \mathrm{kg})$. Selain itu juga terdapat sedikit vitamin E (5-20 mg/kg), flavonoids $(5-50 \mathrm{mg} / \mathrm{kg})$ dan trace elements 
copper (0.1-0.9 mg/kg), manganese (1-1.5 mg/kg) dan zinc (1-2.4 mg/kg). Tomat telah dikenal sebagai sumber utama likopen. Likopen termasuk senyawa karotenoid yang memberikan warna merah pada tomat. Telah dibuktikan bahwa likopen merupakan penangkap radikal bebas yang paling efektif diantara karotenoid yang lain, termasuk jika dibandingkan dengan $\beta$-caroten (12-14).

Meski telah banyak penelitian yang menjelaskan efek antioksidan dan antiinflamasi dari likopen, namun pemberian tomat dalam bentuk jus tanpa proses ekstraksi masih perlu diteliti efektifitasnya. Suplementasi dalam bentuk jus tomat yang relatif lebih murah dan mudah pembuatannya diharapkan dapat menjadi alternatif antioksidan dan antiinflamasi setelah paparan asap rokok. Oleh karena itu, tujuan dari penelitian ini untuk membuktikan adanya pengaruh pemberian jus tomat terhadap penurunan jumlah sel radang di alveolus tikus strain wistar setelah mengalami peningkatan akibat dipapar asap rokok subkronik.

\section{METODE}

Penelitian dilakukan dengan metode eksperimental laboratorik menggunakan hewan coba tikus Rattus norvegicus Strain Wistar sejumlah 20 ekor yang didapatkan dari Laboratorium Farmakologi Fakultas Kedokteran Universitas Brawijaya. Sebelum penelitian dimulai, tikus diaklimatisasi terlebih dahulu selama 1 minggu. Penelitian ini telah dinyatakan memenuhi syarat atau laik etik oleh Komisi Etik Penelitian Kesehatan Fakultas Kedokteran Universitas Brawijaya.

Desain penelitian yang dilakukan adalah randomized post test control group design. Rancangan percobaan yang digunakan adalah rancangan acak lengkap dengan 2 macam perlakuan yaitu paparan dengan asap rokok dan jus tomat dalam berbagai dosis. Hewan coba dibagi menjadi 5 kelompok yaitu kontrol negatif, kontrol positif (dipapar asap rokok), dan 3 kelompok perlakuan (dipapar asap rokok dan diberi jus tomat dengan dosis 1,15; 2,3; 4,6 ml/hari). Masing-masing kelompok terdiri dari 4 tikus.

Pada penelitian ini pemaparan asap rokok jenis kretek menggunakan bantuan alat smoking pump. Dosis pemaparan setiap 3 ekor tikus adalah satu batang rokok kretek per hari selama 9 minggu. Selanjutnya kelompok perlakuan diberi jus tomat $(1,15 ; 2,3$; 4,6 ml/hari) dengan cara disonde. Dosis jus tomat ditentukan berdasarkan perhitungan kandungan likopen yang telah terbukti pada penelitian sebelumnya memiliki efektifitas sebagai antioksidan $(12,15,16)$. Jus tomat dibuat dari tomat yang masak berwarna merah diambil sarinya dengan menggunakan jusser. Tomat yang digunakan adalah tomat merah segar (diharapkan mengandung kadar likopen yang tinggi) yang biasa ada di pasar tradisional (Lycopersicum commune).

Setelah 12 minggu, tikus dieuthanasia dengan menggunakan eter secara inhalasi. Tikus dibedah untuk dikeluarkan jaringan parunya dengan membuka bagian leher secara vertikal dimulai dengan irisan melalui peritoneum ke arah atas. Sediaan histopatologi dibuat dengan cara jaringan paru didehidrasi terlebih dahulu menggunakan alkohol konsentrasi bertingkat. Dilanjutkan dengan proses pencucian menggunakan xylol dan proses infiltrasi dengan paraffin lunak pada suhu $42-46^{\circ} \mathrm{C}$. Setelah dilakukan bloking menggunakan parafin keras pada suhu $46-52{ }^{\circ} \mathrm{C}$, sediaan dipotong menggunakan mikrotom rotary dengan ukuran 4-6 mm. Sediaan yang telah dideparafinasi menggunakan xylol dan direndam dalam alkohol konsentrasi bertingkat selanjutnya diwarna menggunakan Hematoxylin Eosin (HE).

Pengecatan HE dimulai dengan memberian Hematoxylin, dilanjutkan dengan direndam pada alcohol asam dan diberi cairan ammonium. Setelah itu pemberian 
counter staining menggunakan Eosin dilanjutkan dengan dehidrasi menggunakan alcohol konsentrasi bertingkat. Sebelum diamati, dilakukan mounting terhadap sediaan menggunakan etelan. Sediaan diamati pada 10 lapang pandang menggunakan mikroskop perbesaran 400x. Sediaan difoto menggunakan kamera digital tanpa pembesaran sehingga didapatkan gambaran yang sama dengan yang tampak di mikroskop. Selanjutnya dilakukan penghitungan terhadap jumlah sel radang yang sesuai dengan morfologi neutrofil, limfosit, atau makrofag yang terdapat pada septa interalveolaris.

Adanya signifikansi perbedaan antar masing-masing kelompok dianalisis menggunakan metode One Way Anova dan uji Tukey HSD (post - hoc test) kemudian dilanjutkan dengan uji korelasi Pearson untuk melihat pengaruh pemberian jus tomat terhadap jumlah sel radang pada masing-masing perlakuan. Analisis hasil penelitian menggunakan bantuan software SPSS 16.00 for window.

HASIL
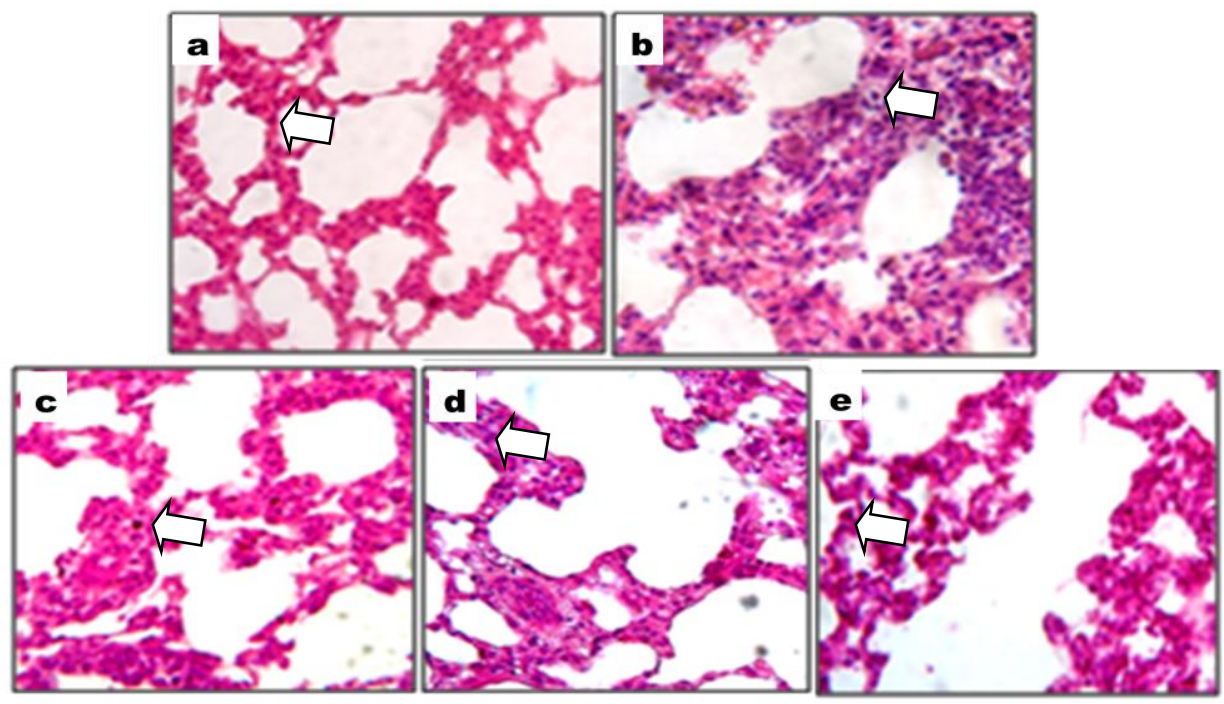

Gambar 1. Gambaran histopatologi jaringan paru tikus dengan pewarnaan HE, perbesaran 400x. (a)kontrol negatif (b)kontrol positif (c)dosis 1, tomat 1,15 ml/hari (d)dosis 2, tomat 2,3 ml/hari (e)dosis 3, tomat 4,6 ml/hari. Nampak adanya perbedaan antar kelompok, dimana gambaran sel radang paling padat terlihat pada kelompok yang dipapar asap rokok subkronik tanpa diberi jus tomat (b). Kelompok yang mendapatkan jus tomat setelah paparan asap rokok (c; d; e) mengalami penurunan ketebalan dinding septa interalveolaris dan jumlah sel radang. ${ }^{*}$ )Tanda panah menunjukkan sel radang.

Berdasarkan gambaran histopatologi dari jaringan paru (gambar 1), penghitungan jumlah sel radang menunjukkan adanya peningkatan pada kelompok kontrol positif yang dipapar asap rokok saja dibanding kelompok kontrol negatif (kelompok yang tidak dipapar asap rokok maupun jus tomat). Sedangkan pada ketiga kelompok perlakuan (kelompok yang dipapar asap rokok dan jus tomat dosis 1,15; 2,3; 4,6 ml/hari) tampak penurunan jumlah sel radang di alveolus dibanding dengan kelompok kontrol positif (gambar 2.A).

Analisis rata-rata jumlah sel radang di alveolus menggunakan uji Oneway Anova diperoleh nilai $p=0,000(p<0,05)$. Hasil uji Tukey HSD menunjukkan bahwa perbedaan 
bermakna terlihat diantara semua kelompok $(\mathrm{p}<0,05)$ kecuali antara kelompok perlakuan dosis 2,3 $\mathrm{ml} /$ hari dengan dosis $4,6 \mathrm{ml} / \mathrm{hari}(\mathrm{p}=0,408)$.

Selanjutnya uji korelasi Pearson menunjukkan nilai signifikansi 0,000, yang dapat diartikan bahwa korelasi antara dosis jus tomat dengan jumlah sel radang di alveolus adalah bermakna. Nilai korelasi Pearson $r=-0,868$ memiliki interpretasi bahwa semakin tinggi dosis maka akan membuat jumlah sel radang alveolus menurun mendekati kontrol negatif jika dibandingkan dengan kontrol positif (gambar 2.B).
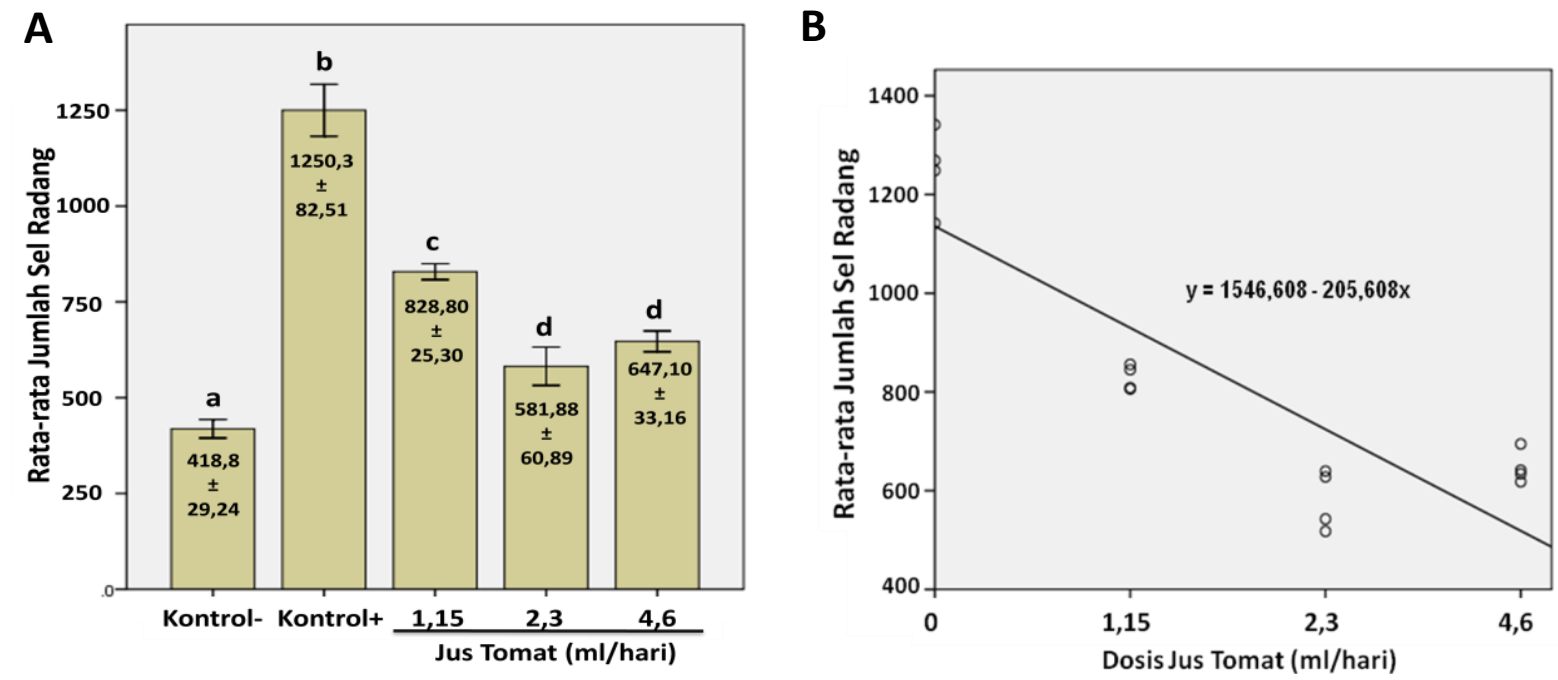

Gambar 2. Pengaruh pemberian jus tomat terhadap jumlah sel radang di alveolus tikus yang dipapar asap rokok subkronik. (A) Grafik rata-rata jumlah sel radang di alveolus jaringan paru tikus dan (B) Grafik linieritas jumlah sel radang pada alveolus terhadap pemberian jus tomat berbagai dosis $(0 ; 1,15 ; 2,3 ; 4,6 \mathrm{ml} /$ hari $)$. Terdapat perbedaan jumlah sel radang di alveolus yang signifikan antara kelompok yang mendapatkan paparan asap rokok tanpa jus tomat (kontrol +) dibandingkan dengan kelompok perlakuan yang mendapatkan jus tomat $(1,15 ; 2,3 ; 4,6 \mathrm{ml} /$ tikus). Grafik linearitas menunjukkan semakin tinggi dosis jus tomat yang diberikan akan diikuti dengan semakin sedikit jumlah sel radang di alveolus. *) Huruf yang berbeda menunjukkan signifikansi $<0.05$

\section{PEMBAHASAN}

Pada penelitian ini, dilakukan pengamatan pengaruh pemberian jus tomat dalam beberapa dosis terhadap jumlah sel radang pada alveolus tikus Wistar yang telah dipapar asap rokok subkronik. Dosis jus tomat yang dicobakan yaitu: 1,15 ml/hari, 2,3 $\mathrm{ml} /$ hari, dan 4,6 ml/hari. Ketiga dosis tersebut setara dengan dosis likopen 7,5 mg/hari, $15 \mathrm{mg} / \mathrm{hari}$, dan $30 \mathrm{mg} / \mathrm{hari}$ pada manusia. Penentuan dosis jus tomat berdasarkan data kebutuhan harian likopen yaitu 6-10 mg perhari pada manusia dan berdasarkan penelitian sebelumnya yang membuktikan bahwa dosis $15 \mathrm{mg}$ likopen per hari pada manusia memiliki efek proteksi yang tinggi dalam menangkap radikal bebas $(12,15,16)$.

Pada alveolus paru tikus wistar kontrol negatif, didapatkan rata-rata jumlah sel radang di alveolus tikus kelompok kontrol negatif sebanyak 418,8 $\pm 29,24$ per lapang pandang. Jumlah ini menggambarkan jumlah sel radang pada septa alveolus tikus normal yang lebih sedikit dibandingkan dengan kelompok lain. Pada kondisi normal sel radang yang ditemukan pada septa alveoli paru berperan dalam proteksi tubuh (17). Jika keberadaan sel radang ini dihubungkan dengan radikal bebas, secara normal radikal bebas terdapat dalam tubuh yang disebut sebagai endogenous free radical. Secara alami, tubuh juga telah memiliki antioksidan sebagai inhibitor yang bekerja 
menghambat oksidasi dengan cara bereaksi dengan radikal bebas yang reaktif membentuk radikal bebas yang relatif stabil (18).

Setelah paparan asap rokok subkronik, rata-rata jumlah sel radang di alveolus tikus kelompok kontrol positif meningkat hingga 1250,3 $\pm 82,51$. Kondisi ini dikarenakan radikal bebas dalam saluran nafas yang meningkat tidak dapat diimbangi oleh antioksidan tubuh sehingga terjadi keadaan stres oksidatif. Radikal bebas secara langsung bekerja pada target sel di saluran pernafasan melalui lipid peroksida (4). Komponen lipid membran sel akan mengalami peroksidasi menghasilkan radikal karbon yang dapat bereaksi dengan oksigen menjadi radikal peroksil. Radikal peroksil ini yang menyerang ulang rantai samping PUFA menghasilkan radikal karbon dan peroksida lipid baru. Peroksida lipid mengakibatkan penurunan fungsi membran plasma dan permeabilitas. Hal ini mendorong terjadinya influks $\mathrm{Ca}^{2+}$ dari ekstraseluler yang menyebabkan peningkatan aktifitas enzim ATP-ase, protease, fosfolipase, dan endonuklease $(19,20)$. Peningkatan aktivitas enzim-enzim ini akan menyebabkan jejas pada sel epithel saluran pernafasan dan alveolus. Jejas pada sel akan menyebabkan pengeluaran mediator-mediator inflamasi sehingga menarik dan meningkatkan jumlah makrofag, neutrofil dan limfosit $(6,8)$.

Inflamasi lokal pada paru-paru yang diinisiasi ROS pada asap rokok tetap terjadi walaupun telah berhenti merokok. Terjadinya smoking-independent oxidant stress ini menjelaskan kenapa jumlah sel radang pada kelompok kontrol positif tetap tinggi walaupun paparan asap rokok telah dihentikan selama 3 minggu (21). Sel radang yang meningkat pada saluran pernafasan dan alveolus akan semakin meningkatkan kondisi stres oksidatif karena sel radang juga menghasilkan oksidan. Peningkatan yang berlebihan dari proses keradangan ini dapat berdampak kerusakan yang luas pada jaringan yang mengalami keradangan kronik $(8,21)$.

Upaya untuk mencegah radikal bebas yang berlebih dalam tubuh dapat dilakukan dengan mengkonsumsi bahan-bahan alam yang mengandung antioksidan sehingga dapat memperkuat proteksi antioksidan dalam tubuh $(22,23)$. Pemberian tomat yang mengandung antioksidan bertujuan untuk mengurangi kondisi stres oksidatif sehingga kondisi inflamasi juga berkurang. Pada penelitian ini telah dibuktikan bahwa pemberian jus tomat selama 3 minggu dengan dosis 1,15 ml/hari, 2,3 ml/hari dan 4,6 ml/hari menyebabkan penurunan jumlah sel radang yang signifikan dibandingkan dengan kelompok yang hanya mendapatkan paparan asap rokok saja.

Studi epidemiologi menunjukkan bahwa kapasitas antioksidan dapat ditingkatkan melalui konsumsi produk tomat, sehingga menurunkan resiko perkembangan penyakit terkait dengan stress oksidatif $(13,15,24)$. Kandungan antioksidan yang menonjol dari tomat adalah carotenoid, terutama likopen dan vitamin $\mathrm{C}$ serta beberapa antioksidan lain yang jumlahnya relatif lebih kecil yaitu vitamin E, flavonoid dan asam fenolat. Terdapat pula trace element yaitu copper, manganese dan zinc serta selenium $(13,14,25)$. Berdasarkan fungsinya, carotenoid dan vitamin C dapat digolongkan sebagai antioksidan sekunder yang berperan dalam menangkap radikal bebas serta mencegah terjadinya reaksi berantai sehingga tidak terjadi kerusakan yang lebih besar (23). Diantara berbagai kandungan tomat, likopen adalah antioksidan yang paling dominan(13). Kemampuan likopen dalam meredam oksigen tunggal bebas dua kali lebih baik dari betakaroten dan sepuluh kali lebih baik daripada alfa-tokoferol. Likopen memiliki kapasitas menangkap radikal bebas yang baik karena strukturnya yang unik berupa banyaknya conjugated double bond (26). Telah terbukti bahwa kadar likopen dalam serum dan jaringan berbanding terbalik dalam hubungannya dengan resiko terjadinya penyakit kronis $(15,27,28)$. 
Pemberian jus tomat $1,15 \mathrm{ml} /$ hari pada tikus, setara dengan suplementasi likopen 7,5 mg/hari, sudah dapat menurunkan jumlah sel radang di alveolus. Hal ini sesuai dengan penelitian sebelumnya bahwa dosis likopen 6,5-30 mg/hari pada manusia sudah cukup memiliki bioavailabilitas sebagai proteksi melawan stress oksidatif $(16,29)$. Pada pemberian jus tomat dengan dosis yang lebih besar jaitu 2,3 ml/hari dan 4,6 ml/hari, jumlah sel radang menurun menjadi lebih sedikit, namun tidak ada perbedaan atara kedua dosis ini. Hal ini selaras dengan penelitian sebelumnya terkait dose response dari efek suplementasi likopen terhadap biomarker stress oksidatif yang menghasilkan peningkatan plasma likopen pada manusia sehat yang relatif sama pada dosis likopen $15 \mathrm{mg} /$ hari dan $30 \mathrm{mg}$ /hari (30).

Selain itu, jus tomat juga mengandung besi (Fe) sebanyak $5 \mathrm{mg} / \mathrm{kg}$ tomat mentah. Kandungan $\mathrm{Fe}$ ini dapat bereaksi dengan vitamin $\mathrm{C}$ membentuk $\mathrm{Fe}^{2+}$ (Fe(III)+Asam Askorbat $\rightarrow \mathrm{Fe}^{2+}+$ askorbat ${ }^{\bullet}$ ). $\mathrm{Fe}^{2+}$ akan bereaksi dengan $\mathrm{H}_{2} \mathrm{O}_{2}$ melalui reaksi Fenton $\left(\mathrm{Fe}^{2+}+\mathrm{H}_{2} \mathrm{O}_{2} \rightarrow \mathrm{OH}^{-}+\mathrm{Fe}^{3+}+\mathrm{OH}^{\bullet}\right)$ dimana produknya yaitu $\mathrm{OH}^{\bullet}$ dapat merusak integritas membran (31). Melalui analisis ini terdapat kemungkinan pada kelompok dosis 4,6 $\mathrm{ml} /$ hari terjadi peningkatan efek antioksidan likopen bersamaan dengan peningkatan radikal hidroksil $\left(\mathrm{OH}^{\bullet}\right)$ yang menginisiasi peroksidasi lipid dan berpotensi merangsang inflamasi (32). Hal ini menyebabkan peningkatan dosis tidak diikuti dengan peningkatan efek antioksidan dan antiinflamasi.

Pada penelitian ini pemberian jus tomat berhasil menurunkan jumlah sel radang di alveoli, namun jika dibandingkan dengan tikus yang sehat secara signifikan jumlah sel radang masih lebih banyak. Hal ini menunjukkan bahwa konsumsi ketiga dosis jus tomat $(1,15 ; 2,3 ; 4,6 \mathrm{ml} /$ hari) selama 3 minggu telah dapat mengurangi kondisi inflamasi di alveolus, namun belum dapat mengembalikan ke kondisi normal.

Hubungan antara dosis jus tomat dengan jumlah sel radang di alveolus diperkuat dengan hasil uji korelasi korelasi Pearson $r=-0,868$ dengan signifikansi $p=0,000$. Hasil ini dapat diinterpretasikan bahwa semakin tinggi dosis jus tomat maka jumlah sel radang di alveolus akan semakin menurun mendekati tikus normal. Jika didasarkan pada penelitian sebelumnya korelasi negatif ini hanya berlaku pada kandungan likopen dosis rendah yang memberi efek antioksidan (30). Dibuktikan pada penelitian ini bahwa pengaruh jus tomat terhadap penurunan jumlah sel radang di alveolus cenderung menetap antara dosis $2,3 \mathrm{ml} /$ hari dan 4,6 ml/hari.

\section{KESIMPULAN}

Berdasarkan fakta dan kajian teori dapat disimpulkan bahwa pemberian jus tomat $(1,15 ; 2,3 ; 4,6 \mathrm{ml} /$ hari $)$ dapat mengurangi kondisi inflamasi pada jaringan paru yang ditandai dengan penurunan jumlah sel radang di alveolus tikus wistar setelah mengalami peningkatan akibat dipapar asap rokok subkronik. Semakin tinggi dosis jus tomat yang diberikan maka semakin sedikit jumlah sel radang pada septum interalveolaris, namun dosis 2,3 $\mathrm{ml} /$ hari dan $4,6 \mathrm{ml} /$ hari tidak berbeda signifikan.

\section{DAFTAR PUSTAKA}

1. Reitsma MB, Fullman N, Ng M, Salama JS, Abajobir A, Abate KH, et al. Smoking prevalence and attributable disease burden in 195 countries and territories, 19902015: a systematic analysis from the Global Burden of Disease Study 2015. Lancet. 2017;389(10082):1885-906.

2. Song Y, Zhao L, Palipudi KM, Asma S, Morton J, Talley B, et al. Tracking mpower in 
14 countries: Results from the global adult tobacco survey, 2008-2010. Glob Health Promot. 2016;23(2):24-37.

3. Taghavi S, Khashyarmanesh Z, Moalemzadeh-Haghighi H, Nassirli H, Eshraghi P, Jalali $\mathrm{N}$, et al. Nicotine content of domestic cigarettes, imported cigarettes and pipe tobacco in iran. Addict Heal [Internet]. 2012;4(1-2):28-35.

4. Valavanidis A, Vlachogianni T, Fiotakis K. Tobacco smoke: Involvement of reactive oxygen species and stable free radicals in mechanisms of oxidative damage, carcinogenesis and synergistic effects with other respirable particles. Int J Environ Res Public Health. 2009;6(2):445-62.

5. Dizdaroglu M, Jaruga P. Mechanisms of free radical-induced damage to DNA. Vol. 46, Free Radical Research. 2012. p. 382-419.

6. Lee J, Taneja V, Vassallo R. Cigarette smoking and inflammation: Cellular and molecular mechanisms. J Dent Res. 2012;91(2):142-9.

7. Bhalla DK, Hirata F, Rishi AK, Gairola CG. Cigarette smoke, inflammation, and lung injury: A mechanistic perspective. Vol. 12, Journal of Toxicology and Environmental Health - Part B: Critical Reviews. 2009. p. 45-64.

8. Qiu F, Liang C-L, Liu H, Zeng Y-Q, Hou S, Huang S, et al. Impacts of cigarette smoking on immune responsiveness: Up and down or upside down? Oncotarget. 2017;8(1):268-84.

9. Maeno T, Houghton a M, Quintero P a, Grumelli S, Owen C a, Shapiro SD. CD8+ T Cells are required for inflammation and destruction in cigarette smoke-induced emphysema in mice. J Immunol. 2007;178:8090-6.

10. Rovina N, Koutsoukou A, Koulouris NG. Inflammation and immune response in COPD: Where do we stand? Vol. 2013, Mediators of Inflammation. 2013.

11. Kingwell K. Lung disease: antioxidant protection against cigarette smoke. Nat Rev Drug Discov. 2009;8(2):110.

12. Ilahy R, Hdider C, Lenucci MS, Tlili I, Dalessandro G. Antioxidant activity and bioactive compound changes during fruit ripening of high-lycopene tomato cultivars. J Food Compos Anal. 2011;24(4-5):588-95.

13. Erge HS, Karadeniz F. Bioactive compounds and antioxidant activity of tomato cultivars. Int J Food Prop. 2011;14(5):968-77.

14. García-Valverde V, Navarro-González I, García-Alonso J, Periago MJ. Antioxidant Bioactive Compounds in Selected Industrial Processing and Fresh Consumption Tomato Cultivars. Food Bioprocess Technol. 2013;6(2):391-402.

15. Story EN, Kopec RE, Schwartz SJ, Harris GK. An Update on the Health Effects of Tomato Lycopene. Annu Rev Food Sci Technol. 2010;1(1):189-210.

16. Rao A V., Shen H. Effect of low dose lycopene intake on lycopene bioavailability and oxidative stress. Nutr Res. 2002;22(10):1125-31.

17. Grommes J, Soehnlein O. Contribution of neutrophils to acute lung injury. Mol Med. 2011;17(3-4):293-307.

18. Amir Aslani B, Ghobadi S. Studies on oxidants and antioxidants with a brief glance at their relevance to the immune system. Vol. 146, Life Sciences. 2016. p. 163-73.

19. Görlach A, Bertram K, Hudecova S, Krizanova O. Calcium and ROS: A mutual interplay. Vol. 6, Redox Biology. 2015. p. 260-71.

20. Hempel N, Trebak M. Crosstalk between calcium and reactive oxygen species signaling in cancer. Vol. 63, Cell Calcium. 2017. p. 70-96.

21. Adcock IM, Caramori G, Barnes PJ. Chronic obstructive pulmonary disease and lung cancer: new molecular insights. Respiration. 2011;81(4):265-84.

22. Van Den Ende W, Peshev D, De Gara L. Disease prevention by natural antioxidants 
and prebiotics acting as ROS scavengers in the gastrointestinal tract. Vol. 22, Trends in Food Science and Technology. 2011. p. 689-97.

23. Nimse, SB, Pal D. Free radicals, natural antioxidants, and their reaction mechanisms. RSC Adv. 2015;5:27986-8006.

24. Erdman JW, Ford NA, Lindshield BL. Are the health attributes of lycopene related to its antioxidant function? Vol. 483, Archives of Biochemistry and Biophysics. 2009. p. 229-35.

25. Periago MJ, García-Alonso J, Jacob K, Olivares AB, Bernal MJ, Iniesta MD, et al. Bioactive compounds, folates and antioxidant properties of tomatoes (Lycopersicum esculentum) during vine ripening. Int J Food Sci Nutr. 2009;60(8):694-708.

26. Kaur A, Dhari J, Sharma OP, Gupta GD, Kharb V. Lycopene. Int J Pharm Technol. 2011;3(4):1605-22.

27. Tanumihardjo SA. Carotenoids and human health. Carotenoids and Human Health. 2013. 1-331 p.

28. Agarwal S, Rao A V. Tomato lycopene and its role in human health and chronic diseases. CMAJ [Internet]. 2000;163(6):739-44.

29. Kamiloglu S, Boyacioglu D, Capanoglu E. The effect of food processing on bioavailability of tomato antioxidants. Vol. 3, Journal of Berry Research. 2013. p. 6577.

30. Devaraj S, Mathur S, Basu A, Meyers S, Jialal I, Aung HH, et al. A Dose-Response Study on the Effects of Purified Lycopene Supplementation on Biomarkers of Oxidative Stress. J Am Coll Nutr. 2008;27(2):267-73.

31. Rahal A, Kumar A, Singh V, Yadav B, Tiwari R, Chakraborty S, et al. Oxidative stress, prooxidants, and antioxidants: The interplay. Vol. 2014, BioMed Research International. 2014.

32. Bouayed J, Bohn T. Exogenous Antioxidants-Double-Edged Swords in Cellular Redox State: Health Beneficial Effects at Physiologic Doses versus Deleterious Effects at High Doses. Oxid Med Cell Longev. 2010;3(4):228-37. 